\title{
Effect of In-ovo Injection of Herbal Extracts on Post-hatch Performance, Immunological, and Physiological Responses of Broiler Chickens
}

\author{
K.H. El-Kholy ${ }^{*}$, Doaa M.A. Sarhan, and Eman A. El-Said \\ Poultry Production Department., Faculty of Agriculture, Damietta University, Damietta, 34518, Egypt \\ *Corresponding author's Email: khelkholy@du.edu.eg; ORCID: 0000-0002-2562-2311
}

\begin{abstract}
In-ovo injection with exogenous materials, such as natural antioxidants, throughout incubation could be a technique to boost hatchlings' performance. The objective of the present study was to determine the effect of in-ovo injection of cinnamon, thyme, and clove extracts on the subsequent growth performances, immunity, and physiological responses of newly-hatched chickens. A total of 450 fertile eggs used in the current experiment were obtained from avian broiler breeder flocks of 28 weeks of age. The eggs were randomly distributed into five treatment groups which included three replicates for each one (30 eggs each group) in a completely randomized design at day 10 of embryogenesis. Treatment groups included a control group (P1: without any injection), the group received an injection of $0.5 \mathrm{ml}$ deionized water ( $\mathrm{P} 2$ : sham group), and the groups injected with $0.1 \mathrm{ml}$ cinnamon, thyme, and clove extracts (P3, P4, P5, respectively). The hatchlings from each treatment were randomly assigned to five replicates of 10 chickens, and reared until 35 days of age. The results showed no significant differences among groups in terms of feed consumption, serum albumin, and immunoglobulin's A (IgA). Nevertheless, using extracts resulted in a significant increase in body weight and weight gain, and improved feed conversion ratio and immunoglobulin's G and M (IgG and IgM), compared to the control and sham groups at 35 days of age. The injected extracts had significantly positive effects on serum lipids profile, liver functions (AST, ALT, and ALP) values, and antioxidant activity, compared to the control groups. Furthermore, serum concentrations of triiodothyronine and thyroxine were significantly higher in the group injected clove-extracted than in other experimental groups. According to the results, it can be concluded that in-ovo injection of herbal extracts, especially clove extract on day 10 of incubation has a positive effect on the broiler chickens' weight at hatch and post-hatch performance as well as physiological, immunological, and anti-oxidative status of hatched chickens.
\end{abstract}

Keywords: Antioxidant, Broiler chicken, Herbal extracts, Immune, In-ovo

\section{INTRODUCTION}

In-ovo injection (IOI) with exogenous materials could be a technique to boost hatchlings' performance (Kadam et al., 2013). Many years ago, in-ovo technology was firstly became offered for the vaccination of broiler hatcheries (Ricks et al., 1999). Then, it had been wonted to deliver nutrients to embryos, since poultry have a restricted supply of nutrients for the development of the embryo (Uni et al., 2012). Thus, alimentary pack and inhibitor capability are also scarce to produce the embryo needs resulting in poor embryo development, reduced hatchability, and low quality of the chickens. Chicken quality covers all the parameters which directly relate to the ability of the chickens to generate a profit. This deficiency is also resolved by the supply of extra sources of essential nutrients and antioxidants via in-ovo administration (Urso et al., 2015). Nowadays, in-ovo feeding of antioxidants throughout incubation may enhance the antioxidant status of the chickens' embryo (EL-Saadany et al., 2019) and post-hatch growth phases (Yigit et al., 2014). Also, in-ovo inoculation of extracts of many plant products have improved chicken immune status against the infectious bursal virus, avian influenza virus (H5N1), and fowl poxvirus (Sood et al., 2012; Nyandoro et al., 2014). In recent years, consideration has been given to the utilization of phytogenic added substances as antioxidant constituents and growth promoters from spice, herbs, and their products (Oke et al., 2017; Oke, 2018) due to their benefits. Among these photobiotic plants, thyme (Thymus vulgaris), cinnamon (Cinnamomum cassia), and cloves (Syzygium aromaticum L.) attract more interest than else (Toghyani et al., 2011; Saki and Salary, 2015; Al-Mufarrej et al., 2019). Cinnamon is a plant containing several compounds, such as cinnamaldehyde, eugenol, and carvacrol (Chang et al., 2013) which have biological 
activities as medical treatment, anti-inflammatory effects, and antioxidant properties (Gurdip et al., 2007). It is also beneficial in poultry production (Sang-Oh et al., 2013); Saeed et al., 2018) and is used as an appetite and digestion stimulant (Toghyani et al., 2011; El-Kholy et al., 2019). Thyme is a plant containing complex mixtures of compounds, such as thymol, carvacrol, tannins, terpenoids, alkaloids, and flavonoids ( Levic et al., 2011). Demirel et al. (2011) and Levic et al. (2011) have reported that thyme is characterized as antimicrobial, antioxidant (Aliyu et al., 2012), and digestive enhancers (Levic et al., 2011). Clove is considered one of the spice herbs containing a large number of biologically active compounds, such as eugenol, eugenol acetate, and $\beta$-caryophyllene (Jimoh et al., 2017), which has attracted considerable attention due to the potent antioxidant and antimicrobial activities standing out among the other spices (Shan et al., 2005). Clove extract is commonly used in the food industry because of its special aroma and natural safety. In addition, the essential oil from clove also exhibited strong antibacterial properties. Clove and its ingredients have been shown to have the appetite and digestion stimulant (Kamel, 2001), potent antimicrobial and antifungal (Ehrich et al., 1995), antiparasitic (Kim et al., 2004), and antioxidant (Dragland et al., 2003) properties. Since antioxidants have a major resistance against free radicals, the qualification of the chicken embryo can be improved by IOI with antioxidants (Salary et al., 2014). Cinnamon, thyme, and clove have all been studied for their effects on broiler growth and physiological responses, and reported that their supplementation improves the performance productive organ characteristics, hematology parameters, immune response of broiler chickens, and biochemical blood status of poultry (Mahrous et al., 2017; Pournazari et al., 2017; Menati et al., 2018; Al-Mufarrej et al., 2019). There is currently little information on the effect of IOI of cinnamon, thyme, and clove extracts.on broiler chicks under Egyptian condition. Therefore, the current study was conducted to elucidate the effect of IOI of cinnamon, thyme, and clove extracts on the productive performance, immunity, and some physiological responses of broiler chickens.

\section{MATERIALS AND METHODS}

\section{Ethical approval}

The present research was carried out in accordance with the Animal Care and Use Committee guidelines of the Damietta University, Damietta, Egypt (Approval number: 03/2018/du.edu). The hatching eggs and chickens in this study were given proper care and management without causing them any unnecessary distress.

\section{Preparation of herbal extracts}

The flowers and leaves of the plant thyme, flowers (cloves), and root (cinnamon), purchased from a local market, were cleaned thoroughly. They were then dried at room temperature, then crushed into a coarse powder, each separately. Weighing out (100 g) of each of these herbal powders, soaking them in $400 \mathrm{ml}$ of distilled water in a conical flask, and vigorously stirring with a glass rod produced the aqueous extract. The mixture was then placed in sterile conical flasks with sterile cotton plugs, and shaken for 12 hours at $200 \mathrm{rpm}$ in a Shaking Incubator (Misung Scientific, Korea) to ensure proper extraction. The combinations were allowed to settle for 24 hours at room temperature. The solution was filtered and concentrated using muslin clothe three times/ herb, after which a clear aqueous extract of the plant was extracted. The extracts were then filtered using Whatman no.1 filter paper. Then, for the hot water extract, the residue was taken and soaked separately in $400 \mathrm{ml}$ of boiled distilled water. That mixture was boiled for 30 minutes into a conical flask, then put for 24 hours at room temperature. The filter paper was used to filter the extract, and the process was repeated three times. The hot and cold extracts were mixed in a conical flask, and stirred vigorously with a glass rod, and kept in Shaker Incubator with $200 \mathrm{rpm}$ for 24 hours. The extracts were kept in a refrigerator at $4^{0} \mathrm{C}$ until being used (Harborn, 1973).

\section{Experimental procedures}

A total number of 450 fertile broiler breeder eggs (Cobb Avian) were obtained from a local hatchary (Abdel-Baki Company, El-Wastany, Damietta, Egypt) from a maternal flock 53 weeks of age. Eggs were normally incubated at $37.7^{\circ} \mathrm{C}$ and $65 \%$ Relative Humidity (RH) in an automatic incubator. On day 10 of incubation, eggs were divided into equal mainly five treatment groups which included three replicates (30 eggs each) in a completely randomized design of incubation. The first group was intact non-injected eggs, considered as the negative control (C), and the second group (Sham group) was injected with $0.1 \mathrm{ml}$ of sterile distilled water, while the third, fourth, and fifth groups were injected into the air cell according to the procedure described by Saeed et al. (2019) with the same amount $(0.1 \mathrm{ml} / \mathrm{egg})$ of cinnamon, thyme, and clove extracts, respectively. The point site of injection was punctured by a hard and thin stylus, and the tested material was injected by using a graded insulin 
syringe ( $1 \mathrm{ml})$, and the punctured site was sealed with nontoxic glue sticks. On day 18 of incubation, all eggs were transferred to the hatcher and kept till hatching at $36.5^{\circ} \mathrm{C}$ and $70 \% \mathrm{RH}$. The weight of newly hatched chickens was assessed at hatch, and 50 chickens per treatment were selected at random and moved to an experimental house for 35 days (marketing age).

\section{Experimental animals}

Chickens of each group were subdivided into five replicates of 10 chickens in each and housed in floor pens $(1.2 \mathrm{~m} \times 1.0 \mathrm{~m} \times 3 \mathrm{~m})$, and the ambient temperature during brooding was $34^{\circ} \mathrm{C} \pm 1$ at two days of age, and gradually reduced to $25^{\circ} \mathrm{C} \pm 1$ on day 21 , and then kept constant. The hatched chickens from the five groups were fed $a d$ libitum on commercial starter (1-25 days old) and grower (26-35 days old) diets. The chemical composition of the basal diet is presented in Table 1. A basal diet was formulated according to NRC (1994).

Table 1. Composition and calculated analysis of starter and grower diets for chickens during the experimental period

\begin{tabular}{lcc}
\hline Ingredients (\%) & Starter & Grower \\
\hline Yellow corn & 58.50 & 62.50 \\
Soybean meal (44\%) & 26.00 & 23.94 \\
Maize gluten meal (62\%) & 10.00 & 7.00 \\
Vegetable oil & 1.500 & 2.50 \\
Limestone & 1.12 & 1.23 \\
Di-Calcium Phosphate & 1.75 & 1.70 \\
Premix* & 0.30 & 0.30 \\
NaCl (salt) & 0.30 & 0.30 \\
L-lysine & 0.36 & 0.36 \\
DL-Methionine & 0.17 & 0.17 \\
Total & 100 & 100 \\
Calculated composition** & & \\
ME*** (kcal kg-1) & 3058.00 & 3120 \\
Crude protein & 22.45 & 20.20 \\
Calcium & 0.93 & 0.95 \\
Non phytate phosphorus & 0.46 & 0.45 \\
Methionine & 0.62 & 0.57 \\
Lysine & 1.28 & 1.2 \\
\hline
\end{tabular}

*The premix at 0.30 of the diet supplies, the following per kg of the diet: A, 1000 I.U., Vit D3 2000 I.U., Vit E, $10 \mathrm{mg}$, Vit K, $1 \mathrm{mg}$, Vit B1, $5 \mathrm{mg}$, Vit B2, $5 \mathrm{mg}$, Vit B6, $1.5 \mathrm{mg}$, Vit B12, $0.01 \mathrm{mg}$, folic acid $0.35 \mathrm{mg}$, Biotin, $0.05 \mathrm{mg}$, Pantothenic acid $10 \mathrm{mg}$, Niacin $30 \mathrm{mg}$, Coline $250 \mathrm{mg}$, $\mathrm{Fe}, 30 \mathrm{mg}, \mathrm{Zn}, 50 \mathrm{mg}, \mathrm{Cu}, 4 \mathrm{mg}$ and $\mathrm{Se}, 0.1 \mathrm{mg}$. **According to NRC (1994). ${ }^{* * *}$ ME: Metablisable Energy.

\section{Performance parameters}

They included averages of Body Weight (BW), Body Weight Gain (BWG), Feed Intake (FI), and Feed Conversion Ratio (FCR), evaluated according to the method described as follow: Average daily Body Weight Gain (BWG) was weekly calculated as the difference between current and previous weight divided by seven days. Daily Feed Intake (FI) and Feed Conversion Ratio (FCR) per bird were calculated weekly. Overall BW gain, FC, and FCR were calculated for the whole duration of the experiment (35 days).

\section{Carcass measurements}

At the end of the experiment ( 35 days of age), five broiler chickens were randomly picked from each replication for carcass evaluation. The birds were slaughtered after being starved (by feed withdrawal overnight) for about 12 hours, then individually weighted to the nearest gram, and slaughtered by severing the jugular veins of the neck with a sharp knife (Siekmann et al., 2018). When complete bleeding was achieved, the hot carcass was weighted. The internal organs (gizzard, Abdominal fat, heart, liver) and lymphoid organs (spleen, thymus, and Bursa) were dissected out, grossly examined, and weighted. The relative weights of these organs were weighted as proportional value to live pre-slaughtering weight.

\section{Biochemical analysis}

Blood samples were collected from five chickens per treatment, during their exsanguinations in weatherman tubes from each group, centrifuged at $4000 \mathrm{rpm}$ for 15 minutes. Serum samples were stored at $-20^{\circ} \mathrm{C}$ until analysis according to guidelines of Herling (2016).

Serum total protein and albumin were measured using a commercial kit as described by the manufacturer company (SpinreactCo., Spain) according to guidelines of Buzanovskii (2017) and Doumas and Maume (1977), respectively. Globulin (Glb, g/dl) values were obtained by subtracting albumin values from the corresponding values of total protein. Serum samples were also analyzed for concentrations of aspartate (AST, U/L) and alanine amino transaminases (ALT, U/L), and alkaline phosphatase (ALP, $\mathrm{mg} / \mathrm{dl}$ ) using commercial kits (Linear Chemicals, Barcelona, Spain) according to the manufacturer procedure. Also, the serum was assayed for Total Cholesterol (TC, $\mathrm{mg} / \mathrm{dl}$ ), Total glycerides (TG, mg/dl), High-density Lipoprotein (HDL, $\mathrm{mg} / \mathrm{dl}$ ), and Low-Density Lipoprotein (LDL, mg/dl) using standard protocol methods (Vogel and Vogel, 1997).

Serum Malondialdehyde (MDA, $\mathrm{nmol} / \mathrm{ml}$ ) was measured following the method described by Janero et al. (1990). Superoxide Dismutase (SOD, U/L) activity was measured based on the ability of SOD to inhibit the reduction of nitrobluetetrazolum superoxide (Martin et al., 1987); one unit of SOD is defined as the amount of sample resulting in $50 \%$ inhibition of nitrobluetetrazolum 
reduction. The serum levels of Immunoglobulin A ( $\operatorname{Ig}$ A), Immunoglobulin $\mathrm{G}$ (IgG), and Immunoglobulin $\mathrm{M}(\mathrm{IgM})$ were determined by ELISA kits (Kamiya Biomedical Company, USA) following the instructions enclosed in the manufactured kits (Elabscience Company, Wuhan, China). Triiodothyronine $\left(\mathrm{T}_{3}\right)$ and thyroxin $\left(\mathrm{T}_{4}\right)$ were determined in sera using the ELISA technique according to Walker (1977).

\section{Statistical analysis}

Data were subjected to the analysis of variance by using a one-way analysis of variance (SAS, 2004). The following fixed model was used:

$$
\mathrm{Y}_{\mathrm{ij}}: \mu+\mathrm{T}_{\mathrm{i}}+\mathrm{e}_{\mathrm{ij}}
$$

where, $Y_{i j}$ is the observation of the $j^{\text {th }}$ chickens in the treatment, $\mu$ : Overall mean, $T_{i}$ denotes the effect of the treatments ( $\mathrm{i}: 1,2,3,4$, and 5), and $\mathrm{e}_{\mathrm{ij}}$ stands for random error component. A probability of $\mathrm{p} \leq 0.05$ was required for statements of significance. Differences among treatment means were detected using Duncan's multiple range test (Duncan, 1955).

\section{RESULTS AND DISCUSSION Performance parameters}

As shown in Table 2, in-ovo administration of herbal extracts significantly $(\mathrm{p} \leq 0.05)$ affected the hatching BW, Final BW, daily weight gain, and FCR during different experimental periods. Among these parameters, only feed intake was not significantly affected. Hatching weight was significantly higher when herbal extracts were received as compared to the control and sham groups. Also, chickens from eggs injected with herbal extracts had better BWG and FCR than the chickens hatched from the control and sham groups throughout the experimental rearing period. During the first days of rearing, chickens mobilized progressively the nutrients as an additional substance to the starter diet given that feed intake was not affected.

Table 2. Effect of in-ovo injection of some herbal extracts on the chickens' weight and subsequent performances of newlyhatched chickens

\begin{tabular}{|c|c|c|c|c|c|c|c|}
\hline \multirow[b]{2}{*}{ Parameters } & \multicolumn{5}{|c|}{ Experimental Treatments } & \multirow[b]{2}{*}{ p value } & \multirow[b]{2}{*}{ SEM ${ }^{*}$} \\
\hline & Control & Sham & $\begin{array}{c}\text { Cinnamon } \\
\text { extract }(0.1 \mathrm{ml})\end{array}$ & $\begin{array}{c}\text { Thyme extract } \\
(0.1 \mathrm{ml})\end{array}$ & $\begin{array}{c}\text { Clove extract } \\
(0.1 \mathrm{ml})\end{array}$ & & \\
\hline Chick weight at hatch (g) & $43.90^{\mathrm{b}}$ & $42.40^{\mathrm{b}}$ & $46.95^{\mathrm{a}}$ & $45.38^{\mathrm{a}}$ & $47.16^{\mathrm{a}}$ & 0.039 & 4.66 \\
\hline Final body weight (g) & $2216.00^{\mathrm{c}}$ & $2223.00^{\mathrm{c}}$ & $2686.00^{\mathrm{b}}$ & $2798.00^{\mathrm{a}}$ & $2847.00^{\mathrm{a}}$ & 0.015 & 206.7 \\
\hline \multicolumn{8}{|l|}{ Weight gain (g) } \\
\hline $1-21$ days of age & $873.10^{\mathrm{ab}}$ & $787.20^{\mathrm{b}}$ & $961.89^{\mathrm{ab}}$ & $1014.13^{\mathrm{a}}$ & $1149.40^{\mathrm{a}}$ & 0.008 & 80.30 \\
\hline 21-35 days of age & $1299.00^{\mathrm{c}}$ & $1393.40^{\mathrm{c}}$ & $1677.20^{\mathrm{b}}$ & $1738.50^{\mathrm{a}}$ & $1650.50^{\mathrm{a}}$ & 0.043 & 171.22 \\
\hline 1-35 days of age & $2172.10^{\mathrm{c}}$ & $2180.60^{c}$ & $26390.10^{\mathrm{b}}$ & $2752.60^{\mathrm{a}}$ & $2799.80^{\mathrm{a}}$ & 0.015 & 262.3 \\
\hline \multicolumn{8}{|l|}{ Feed intake (g) } \\
\hline 1-21 days of age & 1473.68 & 1282.20 & 1400.00 & 1300.00 & 1391.67 & 0.862 & 140.3 \\
\hline 21-35 days of age & 2130.39 & 2183.48 & 1990.00 & 2225.50 & 1973.48 & 0.739 & 161.3 \\
\hline 1-35 days of age & 3604.08 & 3465.67 & 3390.00 & 3525.50 & 3365.14 & 0.975 & 291.5 \\
\hline \multicolumn{8}{|l|}{ Feed conversion ratio } \\
\hline 1-21 days of age & $1.6879^{\mathrm{a}}$ & $1.6288^{\mathrm{a}}$ & $1.4555^{\mathrm{b}}$ & $1.2907^{\mathrm{c}}$ & $1.2138^{\mathrm{c}}$ & 0.001 & 0.04 \\
\hline 21-35 days of age & $1.65^{\mathrm{a}}$ & $1.59^{\mathrm{a}}$ & $1.20^{\mathrm{b}}$ & $1.29^{\mathrm{b}}$ & $1.21^{\mathrm{b}}$ & 0.009 & 0.09 \\
\hline 1-35 days of age & $1.66^{\mathrm{a}}$ & $1.60^{\mathrm{a}}$ & $1.29^{\mathrm{b}}$ & $1.29^{\mathrm{b}}$ & $1.20^{\mathrm{b}}$ & 0.001 & 0.06 \\
\hline
\end{tabular}

"SEM: Standared Error of Mean. ${ }^{a, b, c}$ Means within the raw with different superscripts are significantly different $(\mathrm{p} \leq 0.05)$.

They have been shown to stimulate bile salt secretion and digestive enzyme activities of the intestinal mucosa and pancreas (Dalkiliç and Güler, 2009). The results of the present study were consistent with those previously reported by Nnanle et al. (2017) who found that IOI of natural antioxidant could be improved the chickens' weight at hatch compared to the non-injected groups. Similar results were confirmed by Elwan et al. (2019). In contrary to the present results, Cross et al. (2007) and Abdel-Ghaney et al. (2017) indicated that herbs, plant extracts, essential oil, and/or the main components of the essential oil did not affect the BWG, or feed efficiency in broiler chickens. The results of the current study revealed that IOI of herbal extracts on day 10 of incubation resulted in increasing the chickens' weight at hatch, and this increase may be attributed to the improved antioxidant status of embryos. However, the alleviation of the hatchrelated oxidative stress may lead to a higher hatch weight and post-hatch performance through the protection of skeletal muscle stem cells from oxidative damages (Choi et al., 2016). Also, aromatic plants and their extracts can favorably stimulate endogenous digestive secretions and establish intestinal epithelial structures to influence gut functions (Jang et al. 2007; Yang et al., 2019). So, the in- 
ovo administration of clove extract improved the chick growth performance. The result showed an improvement in the productive performance of broiler chickens due to the present active material in clove (Eugenia caryophyllus) which is considered a digestion stimulating factor, and it had an antibiotic effect against organisms in the digestive canal. Mentioned material caused a greater efficiency in utilization of feed, and led to an improvement in the growth performance (Azadegan et al., 2013). In addition, many studies have reported that clove (Eugenia caryophyllus) was rich in trace minerals which are essential for protein and carbohydrate metabolism, and could improve broiler chickens' performance (AL-Tabari et al., 2018).

\section{Carcass characteristics}

Carcass characteristics of Avian broiler chickens are presented in Table 3, and it was shown that all the examined carcass traits except carcass weight, heart weight, and bursa gland were not affected significantly ( $p$
$>0.05)$ by in-ovo injection of different herbal extracts. AlKassie (2009) reported a significant effect on carcass weight (\%) and internal organs' percentage (liver, heart, and gizzard). A large number of biologically active compounds found in cinnamon, thyme, or clove could be responsible to impulse the immune system.

The Spleen, thymus, and bursa of Fabricius are important immune organs for animals, and their status is closely associated with immune functions. Ravis et al. (1988) reported that the relative weight of immune organs could be used to evaluate the immune status, and greater weights of immune organs usually represent stronger immune functions to some extent. In the present study, IOI of different herbal extracts did not affect the weights of immune organs (spleen and thymus), which was in an agreement with the study of Toghyani et al. (2011), and Mohammad et al. (2019) who found that the diet supplemented with different natural antioxidants did not influence weights of spleen of broiler chickens on 42 days of age.

Table 3. Effect of in-ovo injection of some herbal extracts on carcass characteristics of broiler chickens

\begin{tabular}{|c|c|c|c|c|c|c|c|}
\hline \multirow[b]{2}{*}{ Parameters } & \multicolumn{5}{|c|}{ Treatments } & \multirow[b]{2}{*}{ p value } & \multirow[b]{2}{*}{ SEM" } \\
\hline & Control & Sham & $\begin{array}{c}\text { Cinnamon } \\
\text { extract }(0.1 \mathrm{ml})\end{array}$ & $\begin{array}{c}\text { Thyme extract } \\
(0.1 \mathrm{ml})\end{array}$ & $\begin{array}{c}\text { Clove extract } \\
(0.1 \mathrm{ml})\end{array}$ & & \\
\hline Live body weight (g) & $2216.00^{\mathrm{b}}$ & $2223.00^{\mathrm{b}}$ & $2686.00^{\mathrm{a}}$ & $2798.00^{\mathrm{a}}$ & $2847.00^{\mathrm{a}}$ & 0.0001 & 64.83 \\
\hline Carcass weight $(\%)$ & $79.66^{\mathrm{c}}$ & $79.54^{\mathrm{c}}$ & $82.05^{\mathrm{b}}$ & $83.18^{\mathrm{ab}}$ & $84.56^{\mathrm{a}}$ & 0.0005 & 0.77 \\
\hline Liver weight (\%) & 2.70 & 6.82 & 2.52 & 2.65 & 2.65 & 0.3326 & 0.10 \\
\hline Gizzard weight (\%) & 1.37 & 1.48 & 1.31 & 1.25 & 1.16 & 0.5112 & 0.13 \\
\hline Heart weight $(\%)$ & $0.41^{\mathrm{b}}$ & $0.51^{\mathrm{a}}$ & $0.50^{\mathrm{ab}}$ & $0.54^{\mathrm{a}}$ & $0.47^{\mathrm{ab}}$ & 0.0540 & 0.03 \\
\hline Bursa gland weight (\%) & $0.07^{b}$ & $0.07^{b}$ & $0.11^{\mathrm{a}}$ & $0.13^{\mathrm{a}}$ & $0.13^{\mathrm{a}}$ & 0.0001 & 0.01 \\
\hline Thymus gland weight (\%) & 0.29 & 0.28 & 0.28 & 0.26 & 0.26 & 0.7251 & 0.02 \\
\hline Spleen weight (\%) & 0.17 & 0.17 & 0.23 & 0.22 & 0.21 & 0.1044 & 0.02 \\
\hline Abdominal fat weight (\%) & 1.04 & 0.94 & 0.92 & 0.92 & 0.85 & 0.7130 & 0.09 \\
\hline
\end{tabular}

"SEM: Standared Error of Mean. ${ }^{\mathrm{a}, \mathrm{b}, \mathrm{c}}$ Means within the raw with different superscripts are significantly different $(\mathrm{p} \leq 0.05)$.

\section{Biochemical parameters}

Results of blood biochemical parameters are presented in Table 4. Liver enzymes, globulin fraction, cholesterols, LDL, HDL, and total glycerids levels were significant $(\mathrm{p} \leq 0.05)$ affected by the IOI of herbal extracts in broiler chickens' eggs. The current results were in agreement with Ismail et al. (2019) and Oke et al. (2021) who showed that these blood biochemical traits were significantly affected by IOIs of natural antioxidants (spirulina and black cumin extract). The obtained results also showed that a significant increase in TP and Glb concentration for chickens produced from injected eggs with $0.1 \mathrm{ml}$ clove extract/egg as compared with other experimental groups but these increases were still within the normal range as indicated by the non-sign of toxicity (Table 4). The Alb/Glb ratio showed an opposite trend to that of Glb results, which was higher in the control and sham groups and lower in herbal extracts groups (Table, $3)$. This finding agreed with the results of a study conducted by Tag El-Dein et al. (2020). The decrease in $\mathrm{Alb} / \mathrm{Glb}$ ratio seemed to be due to the increase in $\mathrm{Glb}$ rather than the decrease in Alb. This may reflect the positive increase in immunity through the elevation of the gama-globulin (El-Kholy et al., 2019). The IOI of either thyme or clove broiler chickens' eggs had lower lipids profile than those from the control and sham groups. These results also agreed with the experiments by Mehr et al. (2014) and AL-Tabari et al. (2018) who demonstrated that 
dietary addition of clove extract decreased cholesterol and LDL in broiler chickens. The results released a significant decrease in cholesterol concentration due to the main component of clove (Eugenia caryophyllus), which could be inhibited hepatic 3-nhydroxy -3 methylglutaryl coenzyme (HMG-COA) reductase activity, and led to hypocholesterolemia (Mittal et al., 2014; Shimaa, 2015). In general, hypocholesterolemia might be an indicator that lipid peroxidation was reduced by IOI of either thyme or clove in the broiler chickens' eggs via enhancing antioxidative action. Whereas, antioxidant properties of herbal extracts prevented peroxidation of fatty tissue lipid, especially unsaturated fatty acids. Hypertriglyceridemia effects in chickens fed with cinnamon may be due to active ingredients leading to a decrease in the activity of lipogenic enzymes, and thus it was contributed to reducing re-synthesis (de novo) of fatty acids in the liver and subsequently reducing blood LDL level. Also, the hypocholesterolemia and antihyperlipidemic effect of thyme may be due to the action of thymol and carvacrol on HMG-CoA reductase which reduced fat absorption from the gut or the lipid catabolism for gluconeogenesis (ElGhousein and Al-Beitawi, 2009; Abdulkarimi et al., 2016). Serum ALT, AST and ALP levels were significantly $(\mathrm{p} \leq$ $0.05)$ decreased in the herbal extracts groups in comparison with the control and sham groups. The lowest values were recorded in thyme and clove extracts for ALT and AST, compared to other experimental groups. These results were in partial agreement with koochaksaraie et al. (2011), and Al-Shuwaili et al. (2015) who showed that supplemented groups with garlic 5\%, Ginger 5\%, and cinnamon $5 \%$ reduced $(\mathrm{p} \leq 0.05)$ AST and ALT significantly. Generally, Hernandez et al. (2004) and AlShuwaili et al. (2015) showed that AST and ALT are considered liver enzymes that increase with liver damage (hepatocellular degeneration), so the decrease in AST and ALT may provide evidence for the occurrence of the hepatoprotective effect.

Table 4. Effect of in ovo injection of some herbal extracts on some biochemical parameters of broiler chickens

\begin{tabular}{|c|c|c|c|c|c|c|c|}
\hline \multirow[b]{2}{*}{ Parameters } & \multicolumn{5}{|c|}{ Treatments } & \multirow[b]{2}{*}{ p value } & \multirow[b]{2}{*}{ SEM $^{*}$} \\
\hline & Control & Sham & $\begin{array}{c}\text { Cinnamon } \\
\text { extract }(0.1 \mathrm{ml})\end{array}$ & $\begin{array}{c}\text { Thyme extract } \\
(0.1 \mathrm{ml})\end{array}$ & $\begin{array}{c}\text { Clove extract } \\
(0.1 \mathrm{ml})\end{array}$ & & \\
\hline Total protein $(\mathrm{g} / \mathrm{dl})$ & $4.92^{\mathrm{b}}$ & $4.90^{\mathrm{b}}$ & $5.20^{\mathrm{ab}}$ & $5.26^{\mathrm{ab}}$ & $5.48^{\mathrm{a}}$ & 0.0544 & 0.15 \\
\hline Albumin (g/dl) & 2.50 & 2.54 & 2.56 & 2.50 & 2.58 & 0.8931 & 0.07 \\
\hline Globulin (g/dl) & $2.44^{\mathrm{b}}$ & $2.36^{\mathrm{b}}$ & $2.64^{\mathrm{ab}}$ & $2.76^{\mathrm{a}}$ & $2.90^{\mathrm{a}}$ & 0.0039 & 0.10 \\
\hline $\mathrm{A} / \mathrm{G}$ ratio & $1.03^{\mathrm{ab}}$ & $1.09^{\mathrm{a}}$ & $0.97^{\mathrm{bc}}$ & $0.91^{\mathrm{c}}$ & $0.89^{\mathrm{c}}$ & 0.0004 & 0.03 \\
\hline Cholesterol (mg/dl) & $200.40^{\mathrm{a}}$ & $195.20^{\mathrm{a}}$ & $184.60^{\mathrm{ab}}$ & $169.80^{\mathrm{b}}$ & $168.40^{\mathrm{b}}$ & 0.0032 & 6.07 \\
\hline Total glycerides (mg/dl) & $170.40^{\mathrm{a}}$ & $159.60^{\mathrm{ab}}$ & $139.60^{\mathrm{bc}}$ & $152.00^{\mathrm{abc}}$ & $138.20^{\mathrm{c}}$ & 0.0119 & 6.60 \\
\hline High density liprotein (mg/dl) & $41.80^{\mathrm{b}}$ & $38.80^{\mathrm{b}}$ & $49.00^{\mathrm{a}}$ & $53.40^{\mathrm{a}}$ & $55.20^{\mathrm{a}}$ & 0.0001 & 2.08 \\
\hline Low density lipoprotein (mg/dl) & $124.52^{\mathrm{a}}$ & $124.48^{\mathrm{a}}$ & $107.68^{\mathrm{a}}$ & $86.00^{\mathrm{b}}$ & $85.86^{\mathrm{b}}$ & 0.0001 & 6.20 \\
\hline Aspartate Amino Transaminase (U/L) & $27.00^{\mathrm{ab}}$ & $30.80^{\mathrm{a}}$ & $23.20^{\mathrm{bc}}$ & $21.80^{\mathrm{c}}$ & $20.80^{\mathrm{c}}$ & 0.0023 & 1.68 \\
\hline Alanine amino transaminase (U/L) & $55.85^{\mathrm{ab}}$ & $56.50^{\mathrm{a}}$ & $52.27^{\mathrm{ab}}$ & $48.66^{\mathrm{bc}}$ & $44.31^{\mathrm{c}}$ & 0.0096 & 2.41 \\
\hline
\end{tabular}

"SEM: Standard Error of Mean. ${ }^{\mathrm{a}, \mathrm{b}, \mathrm{c}}$ Means within the raw with different superscripts are significantly different $(\mathrm{p} \leq 0.05)$.

Table 5. Effect of in-ovo injection of some herbal extracts on serum Malondialdehyde, Superoxidedismutase, immunoglobulins, and Triiodothyronine and Thyroxine of broiler chickens

\begin{tabular}{|c|c|c|c|c|c|c|c|}
\hline \multirow[b]{2}{*}{ Parameters } & \multicolumn{5}{|c|}{ Treatments } & \multirow[b]{2}{*}{ p value } & \multirow[b]{2}{*}{ SEM" } \\
\hline & Control & Sham & $\begin{array}{c}\text { Cinnamon } \\
\text { extract }(0.1 \mathrm{ml})\end{array}$ & $\begin{array}{l}\text { Thyme extract } \\
(0.1 \mathrm{ml})\end{array}$ & $\begin{array}{c}\text { Clove extract } \\
(0.1 \mathrm{ml})\end{array}$ & & \\
\hline $\operatorname{MDA}(\mathrm{Mg} / \mathrm{ml})$ & $17.48^{\mathrm{a}}$ & $16.04^{\mathrm{ab}}$ & $13.98^{c}$ & $15.08^{\mathrm{cb}}$ & $14.48^{\mathrm{cb}}$ & 0.0060 & 0.62 \\
\hline $\mathrm{SOD}(\mathrm{U} / \mathrm{ml})$ & $35.16^{\mathrm{d}}$ & $45.04^{\mathrm{cd}}$ & $50.90^{\mathrm{bc}}$ & $64.69^{\mathrm{a}}$ & $60.38^{\mathrm{ab}}$ & 0.0001 & 3.38 \\
\hline $\operatorname{IgG}(\mathrm{mg} / \mathrm{dl})$ & $66.20^{\mathrm{c}}$ & $69.00^{c}$ & $86.20^{\mathrm{b}}$ & $96.40^{\mathrm{a}}$ & $99.60^{\mathrm{a}}$ & 0.0001 & 2.88 \\
\hline $\operatorname{IgA}(\mathrm{mg} / \mathrm{dl})$ & 13.60 & 13.40 & 13.60 & 12.20 & 12.60 & 0.9186 & 1.34 \\
\hline $\operatorname{IgM}(\mathrm{mg} / \mathrm{dl})$ & $23.20^{\mathrm{c}}$ & $24.20^{\mathrm{bc}}$ & $25.20^{\mathrm{ab}}$ & $24.60^{\mathrm{bc}}$ & $26.40^{\mathrm{a}}$ & 0.0250 & 2.66 \\
\hline $\mathrm{T} 4$ (ng/ml) & $17.60^{\mathrm{b}}$ & $16.20^{\mathrm{b}}$ & $17.60^{\mathrm{b}}$ & $17.80^{\mathrm{b}}$ & $23.00^{\mathrm{a}}$ & 0.0026 & 0.15 \\
\hline $\mathrm{T} 3$ (ng/ml) & $0.82^{\mathrm{b}}$ & $0.82^{b}$ & $0.86^{\mathrm{b}}$ & $0.80^{\mathrm{b}}$ & $1.42^{\mathrm{a}}$ & 0.0131 & 0.13 \\
\hline
\end{tabular}

$\overline{{ }_{a}, b, c}$ Means within the raw with different superscripts are significantly different $(\mathrm{p} \leq 0.05)$. ${ }^{\mathrm{I}} \mathrm{MDA}$ : Malondialdehyde, SOD: Superoxide Dismutase, IgG: Immunoglobulin’s G, IgA: Immunoglobulin’s A, IgM: Immunoglobulin’s M, T4: Thyroine, T3: Triiodotyronine. 
Serum malondialdehyde, superoxide dismutase, immunoglobulins, Triiodothyronine, and Thyroxine

Table 5 shows the effect of IOI of herbal extracts on serum Malondialdehyde (MDA), Superoxide Dismutase (SOD), Triiodothyronine (T3), and Thyroxine (T4) of broiler chickens at market age. The serum MDA and SOD of the birds in the groups that received herbal extracts were lower and higher, respectively than that of sham and control groups. The values of T3 and T4 of the chickens injected with herbal extracts, except the group with clove extract, were similar. The levels of $\mathrm{T} 3$ and $\mathrm{T} 4$ of the birds with clove extract were higher than that of other experimental groups. All these results were in agreement with the findings of Oke et al. (2021). Antioxidants have been shown to provide an oxidative defense to the intestines and other organs of developing embryos, protecting them from free radicals that could damage development before hatching (Surai et al., 1999). The use of antioxidants on developing embryos has been reported to confer oxidative protection on the intestines and other organs from free radicals that could impair development before hatching (Surai et al., 1999). Indeed, antioxidant protection is an important mechanism on chickens' development at hatching time (Surai, 2002). Cinnamon Essential Oils (CEO, its main active component is cinnamaldehyde) have been proved to be strong antimicrobials (Chang et al., 2013). Earlier studies have shown that cinnamon, thyme, or clove could be used as a natural antioxidant for avian (Abdel-Ghaney et al., 2017; Yang et al., 2019). Malondialdehyde is a biomarker of lipid peroxidation, and it is used to assess oxidative damage (Jensen et al., 1997). The higher serum SOD in the injected groups than that of the control and sham groups in the present study corroborated the findings of Mostafa et al. (2013) who reported that the use of black cumin as a natural antioxidant resulted in higher SOD in human. The improvement in the oxidative parameters in the chickens received in-ovo herbal extracts in the present study affirmed the observation of Tollba and Hassan (2003) declaring that the use of black cumin relieved the thermal stress effect. The increase in the pattern of the chicken's oxidative parameters at market age as in the present study indicated that the IOI of the herbal extract had a carryover effect on the broiler chickens.

Indeed, previous studies have shown that cinnamon, thyme, and clove possess antioxidant activities which could enhance various enzyme activities including SOD, catalase, and Glutathione-S-transferase which are involved in oxidative stress modulation in broiler chickens. The effect of IOI of herbal extracts on plasma immunoglobulin ( $\operatorname{IgA}, \operatorname{IgG}$, and $\operatorname{IgM})$ in avian hatched chickens are presented in Table 5. Plasma IgG was significantly ( $\mathrm{p} \leq$ 0.05 ) increased in the groups with herbal extracts compared to other groups. On the other hand, plasma concentration of $\operatorname{IgG}$ was increased by $30.2,45.6$, and $50.0 \%$ for the three herbal extracts treatments (cinnamon, thyme, and clove), respectively compared with the control group. On the other hand, either IgA or IgM was not affected by the injection. These findings were confirmed with Abdel-Ghaney et al. (2017) who found that chickens fed diets supplemented with thyme $(0.5 \%)$ achieved the highest values of $\mathrm{IgG}$ than those fed the control diet. Herbs that are rich in flavonoids as thyme extended the activity of vitamin $\mathrm{C}$, acting as antioxidants and, therefore, enhance the immune function (Acamovic and Brooker, 2007). Nadia et al. (2008) found that $0.1 \%$ thyme-fed to laying hens gave better antibody production response compared to 100 or $200 \mathrm{mg} / \mathrm{kg}$ vitamin $\mathrm{E}$ which is a potent immunomodulation. It is well accepted that immunoglobulins can be used to evaluate immune status due to their importance in immune functions. The level of triiodothyronine and thyroxine of the birds of clove extract group in the present study suggested that clove exerts its effects through the thyroid axis. In agreement with present findings, a previous study indicated that herbs, as natural antioxidants, enhance the concentration of thyroxin, thereby positively influence the rate of metabolism.

The concentration of serum $\mathrm{T}_{3}$ and $\mathrm{T}_{4}$ of the chickens that received thyme and cinnamon extracts, were statistically similar to untreated groups (sham and control), indicating that the levels of thyme or cinnamon extracts did not upregulate this hormone differently.

\section{CONCLUSION}

It was concluded that in-ovo injection of herbal extracts, especially clove extract on day 10 of incubation has positive effects on chickens' weight at hatch and posthatch performance as well as the physiological, immunological, and anti-oxidative status of broiler hatched chickens. The mechanisms of in-ovo injection of herbal extracts on the B-cell and T-cell compartments need to be further investigated, especially in avian species.

\section{Competing Interests}

The authors declare that they have no conflict of interest. 


\section{Authors contribution}

K.H.E., E.A.E., and D.M.A.S. developed the concept of the manuscript. K.H.E. wrote the manuscript. All authors checked and confirmed the final revised manuscript.

\section{REFERENCES}

Abdel-Ghaney DM, El-Far AH, Sadek KM, El-Sayed YS, and AbdelLatif MA (2017). Impact of dietary thyme (Thymus vulgaris) on broiler chickens concerning immunity, antioxidant status, and performance. Alexandria Journal of Veterinary Sciences, 55(1): 169-179. DOI: https://www.doi.org/10.5455/ajvs.275352

Abdulkarimi R, Daneshyar M, and Aghazadeh A (2016). Thyme (Thymus vulgaris) extract consumption darkens liver, lowers blood cholesterol, proportional liver and abdominal fat weights in broiler chickens. Italalian Journal of Animal Science, 10(2): e20. DOI: https://www.doi.org/10.4081/ijas.2011.e20

Acamovic T, and Brooker JD (2007). Biochemistry of plant secondary metabolites and their effects in animals. Proceedings of the Nutrition Society, 64(03): 403-412. DOI: https://www.doi.org/10.1079/pns2005449

Aliyu AB, Ibrahim MA, Musa AM, and Oyewale AO (2012). Free radical scavenging and total antioxidant capacity of methanol extract of Ethulia conyzoides growing in Nigeria. Roman. Biotechnology Letter 17(4): 7458-7465. Available at: https://www.e-repository.org/rbl/vol.17/iss.4/6.pdf

Al-Kassie GA (2009). Influence of two plant extracts derived from thyme and cinnamon on broiler performance. Pakistan Veterinary Journal, 29(4): 169-173. Available at: http://www.pvj.com.pk/pdffiles/29_4/169-173.pdf

Al-Mufarrej SI, Fazea EH, Al-Baadani HH, and Qaid MM (2019). Effects of clove powder supplementation on performance, blood biochemistry, and immune responses in broiler chickens. South African Journal of Animal Science, 49(5): 835-844. DOI: https://www.doi.org/0.4314/sajas.v49i5.6

Al-Shuwaili M, Ibrheem E, and Mohammad TN (2015). Effect of dietary herbal plants supplements in turkey diet on performance and some blood biochemical parameters. Global Journal of Bioscience and Biotechnology (G.J.B.B)., 4(1): 85-89. Available at: http://scienceandnature.org/GJBB/GJBB Vol4(2)2015/GJBBV4(2)2015-3.pdf

AL-Tabari AS, AL-Zuhairi ZA, and Abdulrazzaq M (2018). Study the effect of adding aqueous extract of clove (Eugenia caryophyllus) to drinking water in productivity and physiological efficiency of broiler chicken. Basrah Journal of Veterinary research, 17(1): 165175. DOI: https://www.doi.org/10.33762/BVETR.2018.144949

Azadegan M, Hassanabadi A, Nassiri H, and Kermanshahi H (2013). Supplementation of clove essential oils and probiotic to the broilers diet on performance, carcass traits and blood components.Iranian Journal Applied.Animal Science, 4(1): 117-122. Available at: http://ijas.iaurasht.ac.ir/article_513730.htmlBuzanovskii V A (2017). Determination of proteins in blood. Part 1: Determination of Total Protein and Albumin. Review Journal of Chemistry, 7, (1): 79-124. DOI: http://www.doi.10.1134/S2079978017010010

Chang ST, Yeh FH, Luo YC, Lin YC, Cheng SS, and Hsu RY (2013). Methods for thermal stability enhancement of leaf essential oils and their main constituents from indigenous Cinnamon (C. osmophloeum). Journal of Agricultural and Food Chemistry, 61(26): 6293-698. DOI: https://www.doi.org/10.1021/jf401536y

Choi MH, Ow JR, Yang ND, and Taneja R (2016). Oxidative stress mediated skeletal muscle degeneration: molecules, mechanisms, and therapies. Oxidative Medicine and Cellular Longevity. Article ID 6842568. DOI: https://www.doi.org/10.1155/2016/6842568.
Cross DE, McDevitt RM, Hillman K, and Acamovic T (2007). The effect of herbs and their associated essential oils on performance, dietary digestibility and gut microflora in chickens from 7 to 28 days of age. Brtish Poultry Science, 48(4): 496-506. DOI: https://www.doi.org/10.1080/00071660701463221.

Dalkiliç B, and T Güler (2009). The effects of clove extract supplementation on performance and digestibility of nutrients in broilers. Firat Universitesi Saglik Bilimleri Veteriner Dergisi, 23(3): 161-166. Available at: http://veteriner.fusabil.org/pdf/pdf_FUSABIL_677.pdf

Demirel Z, Yilmaz-Koz FF, Karabay-Yavasoglu NU, Ozdemir G, and Sukata A (2011). Antimicrobial and antioxidant activities of solvent extracts and the essential oil composition of Laurencia obtusa and Laurencia obtusa var. pyramidata. Romanian Biotechnology Letters, 16(1): 5927-5936. Available at: https://erepository.org/rbl/vol.16/iss.1/12.pdf

Doumas J, and Maume BF (1977). Metabolic activation by adrenal tissue in rats of a liver carcinogen: safrole. Comptes Rendus des Seances de la Societe de Biologie et de Ses Filiales, 171(1): 108114. Available at: https://pubmed.ncbi.nlm.nih.gov/143305/

Dragland S, Senoo H, Wake K, Holte K, and Blomhoff R (2003). Several culinary and medicinal herbs are important sources of dietary antioxidants. Journal Nutrition, 133: 1286-1290. DOI: https://www.doi.org/10.1093/jn/133.5.1286

Duncan DB (1955). Multiple range and multiple F-Test. International Biometric Society, (11): $1-5$ DOI: https://www.doi.org/10.2307/3001478

Ehrich J, Bauermann U, and Thomann R (1995). Antimicrobial effect of $\mathrm{CO}_{2}$ spice extracts from summer savory to cinnamon. Lebensmitteltechnik, 27(11): 51-53.

El-Ghousein SS, and Al-Beitawi NA (2009). The effect of feeding of crushed thyme (thymus valgaris $l$ ) on growth, blood constituents, gastrointestinal tract and carcass characteristics of broiler chickens. Journal of Poultry Science, 46(2): 100-104. DOI: https://www.doi.org/10.2141/jpsa.46.100

El-Kholy KH, Tag El-Dein HT, Abd-El-Lateif AI, and Mekaouy AI (2019). Effects of dietary selenium sources on metabolic, enzymatic and immunoglobulin serum profiles in growing rabbits. Pakistan Journal Nutrition, 18: 430-436. DOI: https://www.doi.org/10.3923/pjn.2019.430.436

EL-Saadany AS, Ali OM, El Prollosy AA, EL-Barbary AM, Iraqi EE, and Khalil HM (2019). Effect of in ovo injection with resveratrol on hatching traits and physiological response of Mandara chicks. Egyptian of Poultry Science, 39: 973-991. Available at: https://www.epsj.journals.ekb.eg/article_67517_308d6bbe74bea97e 0be623a3f608b1e0.pdf

Elwan HAM, ELnesr SS, Xu Q, Xie C, Don X, and Zou X (2019). Effect of in ovo Methionine-Cysteine injection on embryonic development, antioxidant status, IGF-1and TLR4 Gene expression and iejunum histomorphmetry in newly hatched broiler chicks exposed to heat strees during incubation. Animals (Basel), 9(1): 2529. DOI: https://www.doi.org/ 10.3390/ani9010025

Gurdip S, Sumitra M, DeLampasona MP, and Cesar ANC (2007). A comparison of chemical, antioxidant and antimicrobial studies of cinnamon leaf and bark volatile oils, oleoresins and their constituents. Food and Chemical Toxicology, 45(9): 1650-1661. DOI: https://www.doi.org/10.1016/j.fct.2007.02.031.

Harborn JB (1973). Phytochemical methods. A guide to modern technique of plant analysis. Chapman and hall, London. pp. 173$175 . \quad$ Available at: https://www.springer.com/gp/book/9780412572609

Hernandez F, Madrid J, Garcia V, Orengo J, and Negias MD (2004). Influence of two plant extracts on broiler performance, digestibility and digestive organ size. Poultry Science., 83: 169-174. DOI: https://www.doi.org/10.1093/ps/83.2.169

Herling AW (2016). Techniques of blood collection in laboratory animals. In: F.J. Hock, (Editor), Drug Discovery and Evaluation: 
Pharmacological Assays., Springer International Publishing, Switzerland. DOI: https://www.doi.org/10.1007/978-3-319-053929_132

Ismail FSA, El.Sherif K, Riz YS, and Hassan MEM (2019). Effect of Spirulina and Canthaxanthin injection into hatching eggs on hatchability traits and subsequent growth performance of chicks. Journal of Animal and Poultry Prodution, Mansoura Univ., 10(7): 197-202. https://www.doi.org/10.21608/JAPPMU.2019.53486

Janero DR (1990). Malondialdehyde and thiobarbituric acid-reactivity as diagnostic indices of lipid peroxidation and peroxidative tissue injury. Free Radical Biology and Medicine, 9: 515-540. DOI: https://www.doi.org/10.1016/0891-5849(90)90131-2

Jang IS, Ko YH, Kang SY, and Lee CY (2007). Effect of a commercial essential oil on growth performance, digestive enzyme activity and intestinal microflora population in broiler chickens. Animal Feed Science and Technology, 134: 304-315. DOI: https://www.doi.org/10.1016/j.anifeedsci.2006.06.009

Jensen C, Engberg R, Jakobsen K, Skibsted LH, and Bertelsen G (1997). Influence of the oxidative quality of dietary oil on broiler meat storage stability. Meat Science, 47: 211-222. DOI: https://www.doi.org/10.1016/S0309-1740(97)00052-1

Jimoh AA, Rahmon RO, and Joseph SG (2017). Evaluation of compressive strength characteristics of structural-sized APA (Afzelia bipindensis) and Opon (Lannea schimperi) timber species columns found in Nigeria. Journal of Applied Science and Environmental Management, 21(7): 1281-1285. DOI: https://www.doi.org/10.4314/jasem.v21i7.10

Kadam M, Barekatain MMR, K-Bhanja S, and Iji PA (2013). Prospects of in ovo feeding and nutrient supplementation for poultry: The science and commercial applications-a review. Journal of the Science of Food and Agriculture, 93: 3654-3661. DOI: https://www.doi.org/10.1002/jsfa.6301

Kim SI, Yi JH, Tak JH, and Ahn YJ (2004). Acaricidal activity of plant essential oils against Dermanyssus gallinae (Acari: Dermanyssidae). Veterinary Parasitology, 120: 297-304. DOI: https://www.doi.org/10.1016/j.vetpar.2003.12.016.

Kamel C (2001). Tracing modes of action and the roles of plant extracts in non-ruminants. In: Recent advances in animal nutrition. Garnsworthy PC, and Wiseman J, eds. Nottingham University Press, Nottingham, pp. 135-150. Available at: https://link.springer.com/chapter/10.1007\%2F978-981-15-3024$1 \_13$

Koochaksaraie RR, Irani M, and Gharavysi S (2011). The effects of cinnamon powder feeding on some blood metabolites in broiler chicks. Brazilian Journal of Poultry Science, 13(3): 197-201. DOI: https://www.doi.org/10.1590/S1516-635X2011000300006.

Levic J, Cabarkapa I, Todorovic G, Pavkov S, Sredanovic S, CoghillGalonja T, and Kostadinovic L (2011). In vitro antibacterial activity of essential oils from plant family Lamiaceae. Romanian Biotechnology Letters, 16(2): 6034-6041. Available at: https://www.rombio.eu/rbl2vol16/8\%20Jovanka\%20Levic.pdf

Mahrous HS, El-Far AH, Sadek KM, and Abdel-Latif MA (2017). Effects of different levels of clove bud (Syzygium aromaticum) dietary supplementation on immunity, antioxidant status, and performance in broiler chickens. Alexandria Journal of $\begin{array}{llll}\text { Veterinary } & \text { Sciences, } & \text { 54(2): }\end{array}$ https://www.doi.org/10.5455/ajvs.272231

Martin JPJr, Dailey M, and Sugarman E (1987). Negative and positive assays of superoxide dismutase based on hematoxylin autoxidation. Archives of Biochemistry and Biophysics, 255: 329-336. DOI: https://www.doi.org/10.1016/0003-9861(87)90400-0

Mehr MA, Hassanabadi A, Moghaddam HN, and Kermanshahi H (2014). Supplementation of clove essential oils and probiotic to the broiler's diet on performance, carcass traits and blood components. Iranian Journal of Applied Animal Science, 4: 117122. Available at: http://ijas.iaurasht.ac.ir/article 513730.html
Menati JK, Ali NAL, and Abidelhuseen HS (2018). Effect of using different concentrations of the aqueous extract for thymus leaves in some physiological, histological and immunological traits for broiler chicks. Advances in Animal and Veterinary Sciences, 6(10): 406-412.

DOI: https://www.doi.org/10.17582/JOURNAL.AAVS/2018/6.10.406.41 $\underline{2}$

Mittal, M., Gupta, N., Parashar, P., Mehra, V., \& Khatri, M. (2014). Phytochemical evaluation and pharmacological activity of Syzygium aromaticum: a comprehensive review. International Journal of Pharmacy and Pharmaceutical Sciences, 6(8), 67-72. Available https://innovareacademics.in/journals/index.php/ijpps/article/view/2 $\underline{055}$

Mohammad NG, El-wardany IE, El-homosany YM, Wakwak MM, Sabic EM, and Ibrahim NS (2019). In-ovo inculation of selenium nanoparticles improves productive performance, blood biochemical profile, antioxidant status and immune response of hatched chicks. In: Proceeding of the 14th Conference of Agriculture Development Research, Faculty of Agriculture, Ain Shams University, March, 2019, Cairo, Egypt Special Issue, 27(1): 887-897. Available at: http://strategy-plan.asu.edu.eg/AUJASCI/

Mostafa RM, Moustafa YM, Mirghani Z, AlKusayer GM, and Moustafa KM (2013). Antioxidant effect of garlic (Allium sativum) and black seeds (Nigella sativa) in healthy postmenopausal women. SAGE Open Med. 1, DOI: https://www.doi.org/10.1177/2050312113517501

Nadia LR, Hassan RA, Qota EM, and Fayek HM (2008). Effect of natural antioxidant on oxidative stability of eggs and productive and reproductive performance of laying hens. International Journal of Poultry Science, $7(2)$ : 134-150. DOI: https://www.doi.org/10.3923/IJPS.2008.134.150

Nnanle O, Tété-Bénissan A, Tona JK, Teteh A, Voemesse K, Decuypere E, and Gbeassor M (2017). Effect of in ovo inoculation of Moringa oleifera leaves extract on hatchability and chicken growth performance Europian.Poultry Science, 81: 1612-9199. DOI: https://www.doi.org/10.1399/eps.2017.213

National Research Council (NRC) (1994). Nutrient requirements of poultry $\left(9^{\text {th }}\right.$ rev. Ed.) National Academy Press. Washington, D.C., USA pp. 26-34. DOI: https://doi.org/10.17226/2114

Nyandoro SS, Nkunya MHH, Cosam JC, and Msoffe PLM (2014). In ovo antiviral potency of the leaf constituents of Tanzanian Toussaintia species against infectious bursal disease virus and Newcastle disease virus. International Journal of Biology and Chemestry Science. 8: 1308-1318. Available at: https://www.researchgate.net/publication/277474687

Oke OE, Oyelola OB, Iyasere OS, Njoku CP, Oso AO, Oso OM, Fatoki ST, Bankole KO, Jimoh IO, Sybill NI et al. (2021). In ovo injection of black cumin (Nigella sativa) extract on hatching and post hatch performance of thermally challenged broiler chickens during incubation. Poultry Science, 100: 100831. DOI: https://doi.org/10.1016/j.psj.2020.10.072

Oke OE, Emeshili UK, Iyasere OS, Abioja MO, Daramola JO, Ladokun AO, Abiona JA, Williams TJ, Rahman SA, Rotimi SO et al. (2017). Physiological responses and performance of broiler chickens offered olive leaf extract under a hot humid tropical climate. Journal of Applied Poultry Research, 26: 376-382. DOI: https://www.doi.org/10.3382/japr/pfx005

Oke OE (2018). Evaluation of physiological response and performance by supplementation of Curcuma longa in broiler feed under hot humid tropical climate. Trop. Anim. Health Pro. 50: 1071-1077. DOI: https://doi.org/10.1007/s11250-018-1532-8.

Pournazari M, Qotbi AAA, Seidavi A, and Corazzin M (2017). Prebiotics, probiotics and thyme (Thymus vulgaris) for broilers: performance, carcass traits and blood variables. Revista Colombiana de Ciencias Pecuarias, 30(1): 3-10. DOI: https://www.doi.org/10.17533/udea.rccp.v30n1a01. 
Ravis WR, Parsons DL, and Wang SJ (1988). Buffer and pH effects on propranolol binding by human albumin and $\alpha 1$-acid glycoprotein. Journal of Pharmacy and Pharmacology, 40: 459-463. DOI: https://www.doi.org/10.1111/j.2042-7158.1988.tb05277.x

Ricks CA, Avakian A, Bryan T, Gildersleeve R, Haddad E, Ilich R, King S, Murray L, Phelps P, Poston R et al. (1999). In ovo vaccination technology. Advances in Veterinary Medicine, 41: 495-515. Available at: https://pubmed.ncbi.nlm.nih.gov/9890038/

Saki AA, and Salary J (2015). The impact of in ovo injection of silver nanoparticles, thyme and savory extracts in broiler breeder eggs on growth performance, lymphoid-organ weights, and blood and immune parameters of broiler chicks. Poultry Science, 3(2): 165172. DOI: https://www.doi.org/10.22069/PSJ.2015.2655Saeed M, Kamboh AA, Syed SF, Babazadeh D, Suheryani I, Shah QA, Umar M, Kakar I, Naveed M, Abd El-Hack ME, Alagawany M and Chao S (2018) Phytochemistry and beneficial impacts of cinnamon (Cinnamomum zeylanicum) as a dietary supplement in poultry diets, World's Poultry Science Journal, 74:2, 331-346, DOI: https://www.doi.org/10.1017/S0043933918000235

Saeed M, Babazadeh D, Naveed M, Alagawany M, Abd El-Hack ME, Arain MA, Tiwari R, Sachan S, Karthik K, Dhama K, Elnesr SS and Sun Chao S (2019). In ovo delivery of various biological supplements, vaccines and drugs in poultry: current knowledge. Journal of the Science of Food and Agriculture, 99(8): 3727-3739. DOI: https://doi.org/10.1002/jsfa.9593

Salary J, Sahebi-Ala F, Kalantar M, and Matin HRH (2014). In ovo injection of vitamin $\mathrm{E}$ on post-hatch immunological parameters and broiler chicken performance. Asian Pacific Journal of Tropical Biomedicine, 4(2): 616-619. Available at: https://core.ac.uk/download/pdf/81945247.pdf

Sang-Oh P, Chae MR, Byung-Sung P, and Jong H (2013). The meat quality and growth performance in broiler chickens fed diet with cinnamon powder. Journal of Environmental Biology, 34(1): 127133. Available at: https://pubmed.ncbi.nlm.nih.gov/24006819/

(SAS) Statistical Analysis System (2004). Statistical Analysis System, User's Guide. Statistical. Version $7^{\text {th }}$ ed. SAS. Inst. Inc. Cary. N.C. USA.

Shan B, Cai YZ, Sun M, and Corke H (2005). Antioxidant capacity of 26 spice extracts and characterization of their phenolic constituents. Journal of Agriculture and Food Chemistry, 53(20): 77497759. DOI: https://www.doi.org/10.1021/jf051513y

Shimaa MH (2015). Effect of Some Levels of Cardamom,Clove and Anise on Hepatotoxicity in Rats Caused by CCL4. World Applied $\begin{array}{llll}\text { Sciences Journal, 33(6): 854-865. DOI: } & \end{array}$ https://www.doi.org/10.5829/idosi.wasj.2015.33.06.14589

Siekmann L, Meier-Dinkel L, Janisch S, Altmann B, Kaltwasser C, Sürie $\mathrm{C}$ and Krischek C (2018). Carcass quality, meat quality and sensory properties of the dual-purpose chicken lohmann dual. Foods, 7(10), 156. DOI: https://www.doi.org/10.3390/foods7100156

Sood R, Swarup D, Bhatia S, Kulkarni DD, Dey S, Saini M, and Dubey SC (2012). Antiviral activity of crude extracts of Eugenia jambolana Lam. against highly pathogenic avian influenza (H5N1) virus. Indian Journal of Experimental Biology, 50(3): 179-186. Available at: https://pubmed.ncbi.nlm.nih.gov/22439432/

Surai PF (2002). Natural Antioxidants in Avian Nutrition and Reproduction. Nottingham University Press, Nottingham, UK. Available at: https://www.researchgate.net/publication/313619662

Surai PF, Noble RC, and Speake BK (1999). Relationship between vitamin $\mathrm{E}$ content and susceptibility to lipid peroxidation in tissues of the newly hatched chick. British. Poultry Science, 40: 406-410. DOI: https://www.doi.org/10.1080/00071669987520

Tag El-Dein H, Samar Rakha and El-Kholy, KH (2020). Determination of some physiological and immunological characterisation as dietary biological addition on broiler chicks. J. of Animal and Poultry Production, Mansours Univ., 11(7): 243-247. DOI: https://www.doi: 10.21608/JAPPMU.2020.108805

Toghyani M, Gheisari A, Ghalamkari G, and Eghbalsaied S (2011). Evaluation of cinnamon and garlic as antibiotic growth promoter substitutions on performance, immune responses, serum biochemical and haematological parameters in broiler chicks. Livestock Science, 138(1): 167-173. DOI: https://www.doi.org/10.1016/j.livsci.2010.12.018

Tollba A, and Hassan A (2003). Using some natural additives to improve physiological and productive performance of broiler chicks under high temperature conditions. 1- Thyme (Thymus vulgaris l.) or Fennel (Foniculum vulgare l.). Egyptian Journal of Poultry Science, 23(II): 313-326.

Uni Z, Yadgary L, and Yair R (2012). Nutritional limitations during poultry embryonic development. Journal of Applied Poultry Research, 21: 175-184. DOI: https://www.doi.org/10.3382/japr.2011-00478

Urso UR, Dahlke F, Maiorka A, Bueno IJ, Schneider AF, Surek D, and Rocha C (2015). Vitamin E and selenium in broiler breeder diets: Effect on live performance, hatching process, and chick quality. Poultry Science, 94: 976-983. DOI: https://www.doi.org/10.3382/ps/pev042

Vogel G, and Vogel WH (1997). Influence of lipid metabolism. In: Drug Discovery and Evaluation Pharmacological Assay, Springer-Verly, Berloin, pp. 604-608. DOI: https://doi.org/10.1177/026988119801200315

Walker B (1977). Productivity of macroptilium atropurpureum cv. Siratro pastures. Tropical Grassland, 11(1): 79-86. Available at: https://www.feedipedia.org/node/15434

Yang Yun-feng, Zhao Lu-lu, Shao Yu-xin, Liao Xiu-dong, Zhang Liyang, Lu Lin, and LUO Xu-gang (2019). Effects of dietary graded levels of cinnamon essential oil and its combination with bamboo leaf flavonoid on immune function, antioxidative ability and intestinal microbiota of broilers. Journal of Integrative Agriculture, 18(9): 2123-2132. DOI: https://www.doi.org/10.1016/S20953119(19)62566-9

Yigit AA, Panda AK, and Cherian G (2014). The avian embryo and its antioxidant defence system. Worlds of Poultry Science Journal, 70: 563-574. DOI: https://www.doi.org/10.1017/S0043933914000610 